\title{
Soil exchangeable base cations along a chronosequence of Caragana microphylla plantation in a semi-arid sandy land, China
}

\author{
YuGe ZHANG ${ }^{1,2}$, ZhuWen XU ${ }^{2}$, DeMing JIANG ${ }^{2}$, Yong JIANG ${ }^{2 *}$ \\ ${ }^{1}$ College of Biological and Environmental Engineering, Shenyang University, Shenyang 110044, China; \\ ${ }^{2}$ State Key Laboratory of Forest and Soil Ecology, Institute of Applied Ecology, Chinese Academy of Sciences, Shenyang \\ 110164, China
}

\begin{abstract}
As a pioneer leguminous shrub species for vegetation re-establishment, Caragana microphylla is widely distributed in the semi-fixed and fixed sandy lands of the Horqin region, North China. C. microphylla plantations modify organic carbon ( $\mathrm{SOC}$ ), nitrogen $(\mathrm{N})$ and phosphorus dynamics, bulk density and water-holding capacity, and biological activities in soils, but little is known with regard to soil exchange properties. Variation in soil exchangeable base cations was examined under $C$. microphylla plantations with an age sequence of $0,5,10$, and 22 years in the Horqin Sandy Land, and at the depth of 0-10, 10-20, and 20-30 cm, respectively. C. microphylla has been planted on the non-vegetated sand dunes with similar physical-chemical soil properties. The results showed that exchangeable calcium (Ca), magnesium (Mg), and potassium (K), and cation exchange capacity (CEC) were significantly increased, and $\mathrm{Ca}$ saturation tended to decrease, while $\mathrm{Mg}$ and $\mathrm{K}$ saturations were increased with the plantation years. No difference was observed for exchangeable sodium $(\mathrm{Na})$ neither with plantation years nor at soil depths. Of all the base cations and soil layers, exchangeable $\mathrm{K}$ at the depth of $0-10 \mathrm{~cm}$ accumulated most quickly, and it increased by $1.76,3.16$, and 4.25 times, respectively after $C$. microphylla was planted for 5,10 , and 22 years. Exchangeable $\mathrm{Ca}, \mathrm{Mg}$, and $\mathrm{K}$, and CEC were significantly $(P<0.001)$ and positively correlated with SOC, total $\mathrm{N}, \mathrm{pH}$, and electrical conductivity (EC). Soil $\mathrm{pH}$ and $\mathrm{SOC}$ are regarded as the main factors influencing the variation in exchangeable cations, and the preferential absorption of cations by plants and different leaching rates of base cations that modify cation saturations under $C$. microphylla plantation. It is concluded that as a nitrogen-fixation species, $C$. microphylla plantation is beneficial to increasing exchangeable base cations and CEC in soils, and therefore can improve soil fertility and create favorable microenvironments for plants and creatures in the semi-arid sandy land ecosystems.
\end{abstract}

Keywords: cation exchange capacity; soil organic carbon; soil pH; soil fertility; Caragana microphylla; ecological restoration

Citation: YuGe ZHANG, ZhuWen XU, DeMing JIANG, Yong JIANG. 2013. Soil exchangeable base cations along a chronosequence of Caragana microphylla plantation in a semi-arid sandy land, China. Journal of Arid Land, 5(1): 42-50.

Caragana microphylla is a long-lived perennial deciduous shrub species, and is widely distributed in the sandy lands of Inner Mongolia, the steppe zone of the Songliao Plain and the mountainous forest zone of North China (Zhao, 2005). As a pioneer leguminous shrub species for vegetation re-establishment, C. microphylla is widely distributed in the semi-fixed and fixed sandy lands of the Horqin region (Cao et al.,
2011). It is well adapted to moving sand dunes, resistant to heat, cold, drought, wind erosion, sand burial and hail storm, and forms nitrogen-fixing modules (Yue et al., 2008; Wang et al., 2010).

Many researches related to C. microphylla plantations focused on plant productivity (Ma et al., 2004), cycling of soil $\mathrm{C}$ and $\mathrm{N}, \mathrm{P}$, and $\mathrm{K}$ nutrients ( $\mathrm{Su}$ and Zhao, 2003; Su et al., 2005; Kondo et al., 2012), soil

*Corresponding author: Yong JIANG (E-mail: jiangyong@iae.ac.cn)

Received 2012-04-15; revised 2012-07-11; accepted 2012-11-07

(C) Xinjiang Institute of Ecology and Geography, Chinese Academy of Sciences, Science Press and Springer-Verlag Berlin Heidelberg 2013 
fauna (Jiang et al., 2007), or soil microbial activities (Cao et al., 2008, 2011). Only a few involved soil exchangeable base cations and cation exchange capacity (CEC).

The interactions between soil exchange properties and other physical, chemical, and biological properties in soil control plant nutrient availability (Havlin et al., 2004). Calcium (Ca), magnesium ( $\mathrm{Mg}$ ), and potassium (K) are essential elements and important macronutrients in terrestrial ecosystems, and interactions between these dominant base cations and other nutrients, such as nitrogen $(\mathrm{N})$ and phosphorus $(\mathrm{P})$, are potentially important for the health and stability of ecosystems (Lucas et al., 2011). Exchangeable base cations and CEC vary a lot with different organic matter fractions (Oorts et al., 2003), soil particle sizes (van Erp et al., 2001), soil pH (Katou, 2002), land use change (Jiang et al., 2009), cation migration characteristics, the eluviation-illuviation processes, alternative reducing-oxidizing conditions, the selective absorption of cations by plants, and some other pedogenic and anthropogenic conditions (Favre et al., 2002; Jiang et al., 2005). In general, it is well documented that soil CEC increases with clay or soil organic matter (SOM) increases, and the CEC of most soils increases with an increase in soil $\mathrm{pH}$ as well. Clay soils of high CEC tend to have a greater water-holding capacity than sandy soils of low CEC, and high CEC soils are more able to retain base cations, while low CEC soils are more likely to be deficient of $\mathrm{K}$ and $\mathrm{Mg}$ and other cations.

It is basically clear that soil chemical properties such as $\mathrm{SOC}, \mathrm{N}, \mathrm{P}$, and soil $\mathrm{pH}$, and physical features such as bulk density, water-holding capacity, and biological activities related to soil fauna, microbes and enzyme change a lot under C. microphylla plantations or beneath natural shrubs. Our hypothesis was that soil exchangeable cations and CEC would change along with soil physical-chemical and biological properties under C. microphylla plantations, and hence, the objectives of this study were to examine the variation in soil exchangeable cations and CEC along a chronosequence of C. microphylla plantations, and to identify factors contributing to the variation in base cations and CEC.

\section{Materials and methods}

\subsection{Study area}

The study was conducted at the Wulanaodu Desertification Experimental Station $\left(43^{\circ} 02^{\prime} \mathrm{N}, 119^{\circ} 39^{\prime} \mathrm{E}\right)$, Chinese Academy of Sciences, southwestern Horqin Sandy Land of Northeast China. The station is located in a semi-arid continental temperate monsoon zone, with an annual average temperature of $6.3^{\circ} \mathrm{C}$, and an average annual frost-free period of 130 days. The average annual precipitation is $340 \mathrm{~mm}$, with $70 \%-80 \%$ occurring during May-September, and the annual pan-evaporation averages about $2,500 \mathrm{~mm}$. The typical landscape is gently undulating moving and semi-moving sand dunes with inter-dune bottomlands. The soil, which is sandy in texture, light yellow in color, loose in consistence, low in organic matter, and susceptible to wind erosion, is classified as Typic Usti-Sandic Primosols in Chinese Soil Taxonomy (CRGCST, 2001) or Haplic Arenosols in FAO Soil Taxonomy (FAO, 1988). C. microphylla has been selected as an experimental plant for ecological restoration of non-vegetated sandy dunes since the early 1980s. The experimental sites were enclosed after seeding of C. microphylla, and shrubby belts were formed 3-5 years after seeding. Gradually, short grasses, legumes and forbs colonized, and a stabilized shrubby-grass vegetation system was established. In this study, three C. microphylla plantations with an age sequence of 5, 10, and 22 a, and adjacent nonvegetated sand dunes $(0-a)$ were selected as experimental treatments.

\subsection{Sampling and soil analyses}

In April 2006, mixed soil samples were collected at the depths $0-10,10-20$ and $20-30 \mathrm{~cm}$. We selected four sampling sites from different sand dunes with the same age of C. microphylla plantation. At each site, five sub-samples were collected with a shovel, and were then mixed as one sample. A total of 48 soil samples were collected from four treatments, replicated four times at three soil layers. All soil samples were air-dried and ground to pass through a 2-mm sieve, and the sub-samples were ground to pass through a $0.149-\mathrm{mm}$ sieve for related chemical analysis.

Because the shrubs in this study were established 
from non-vegetated sandy dunes, it was assumed that the soils at each site were similar prior to C. microphylla plantation. In fact, the data obtained from previous and recent studies at the sites have shown that soil texture and organic matter content were not significantly different in the unstable dunes over time, suggesting that the soils were relatively similar in these characteristics before planting (Cao et al., 2008), and hence the changes of soil properties were assumed to come from the plantation time of C. microphylla.

Soil exchangeable $\mathrm{Ca}, \mathrm{Mg}, \mathrm{K}$ and $\mathrm{Na}$ were extracted with $1 \mathrm{M} \mathrm{NH}$-acetate $\left(\mathrm{NH}_{4} \mathrm{OAc}, \mathrm{pH} 7\right)$, and the extracts were then analyzed for exchangeable $\mathrm{Ca}$, $\mathrm{Mg}, \mathrm{K}$ and $\mathrm{Na}$ by flaming emission at the wavelength of 422.7, 285.2, 766.5 and $589.0 \mathrm{~nm}$, respectively, using atomic absorption spectrophotometer (AAS, Shimadzu, Japan). Because in the study site, soil $\mathrm{pH}$ is higher than 7 , and the sum of exchangeable cations accounts for more than $99 \%$ of the CEC, we just calculated the cation exchange capacity by adding up the total amount of exchangeable $\mathrm{Ca}, \mathrm{Mg}, \mathrm{K}$ and $\mathrm{Na}$ measured above. Base saturation (\%) was calculated by dividing the charge equivalents of base cations by CEC and multiplying by 100 . Soil $\mathrm{pH}$ was measured with combined electrodes in a 1:2.5 soil:water suspension. Soil electrical conductivity (EC) was measured using electrodes in a 1:2 soil:water suspension. Soil organic carbon and total nitrogen contents were determined by the dry combustion method using a Vario ELIII Elemental Analyzer (Elementar, Germany). China's national standard soil reference materials (GBW07424 and GBW07458) were adopted through the digestion, extraction and analysis procedures as a part of the QA/QC protocol.

\subsection{Statistical analysis}

The obtained data were analyzed with SPSS Version 11.5 for Windows, using one-way ANOVA and Duncan's pairwise comparison for means separation, and a significance level of $P<0.05$ was chosen for detecting significant differences. Univariate analysis of variance was adopted to test inter-subject effects with plantation year and soil depth as factors. Simple correlation coefficients and linear regression analysis were performed to examine the relationship between some soil chemical properties. Figures were drawn using SigmaPlot 11.0 (Systat Software Inc.).

\section{Results}

\subsection{Soil exchangeable base cations under different plantation years of $\boldsymbol{C}$. microphylla}

Univariate analysis of variance showed that soil exchangeable $\mathrm{Ca}, \mathrm{Mg}, \mathrm{K}$, and cation exchange capacity $(\mathrm{CEC})$ varied significantly $(P<0.001)$ with different plantation years, and exchangeable $\mathrm{Ca}, \mathrm{K}$, and $\mathrm{CEC}$ varied significantly at different soil depths, but no difference was observed for exchangeable $\mathrm{Na}$ with neither plantation years nor depths. No significant inter-subject effect was tested for exchangeable base cations or CEC (Table 1).

Soil exchangeable $\mathrm{Ca}, \mathrm{Mg}, \mathrm{K}$, and $\mathrm{CEC}$ increased significantly in 5-, 10-, and 23-a C. microphylla plantations at $0-10,10-20$, or $20-30 \mathrm{~cm}$ soil layer, respectively, but no significant change was observed for ex-

Table 1 Univariate variance analysis for soil chemical properties in different C. microphylla plantation years and at different soil depths

\begin{tabular}{|c|c|c|c|c|c|c|}
\hline \multirow{2}{*}{ Variable } & \multicolumn{2}{|c|}{ Plantation year } & \multicolumn{2}{|c|}{ Soil depth } & \multicolumn{2}{|c|}{ Plantation year $\times$ soil depth } \\
\hline & $F$ value & $P$ & $F$ value & $P$ & $F$ value & $P$ \\
\hline Exchangeable $\mathrm{Ca}$ & 10.07 & $<0.001$ & 4.24 & 0.022 & 0.42 & 0.862 \\
\hline Exchangeable $\mathrm{Mg}$ & 5.18 & $<0.001$ & 1.07 & 0.355 & 0.55 & 0.771 \\
\hline Exchangeable $\mathrm{K}$ & 35.10 & $<0.001$ & 22.42 & $<0.001$ & 2.24 & 0.061 \\
\hline Exchangeable $\mathrm{Na}$ & 2.12 & 0.115 & 1.00 & 0.378 & 0.65 & 0.701 \\
\hline Cation exchange capacity & 22.52 & $<0.001$ & 8.43 & 0.001 & 0.54 & 0.773 \\
\hline Soil organic carbon & 137.58 & $<0.001$ & 31.11 & $<0.001$ & 3.72 & 0.006 \\
\hline Total nitrogen & 23.75 & $<0.001$ & 28.29 & $<0.001$ & 4.71 & 0.001 \\
\hline Soil pH & 36.93 & $<0.001$ & 3.34 & 0.047 & 0.16 & 0.987 \\
\hline Electrical conductivity & 53.07 & $<0.001$ & 19.98 & $<0.001$ & 1.08 & 0.388 \\
\hline
\end{tabular}


changeable $\mathrm{Na}$, relative to the non-vegetated sand dunes (Fig. 1). As compared with non-vegetated sand dunes $(0-a)$, the average content of CEC at the depth of $0-10 \mathrm{~cm}$ increased by $32.56 \%, 45.35 \%$, and $57.09 \%$, respectively in 5-, 10-, and 22-a C. microphylla plantations; exchangeable $\mathrm{Ca}$ increased by $29.14 \%, 38.56 \%$, and $46.11 \%$, respectively in $5-, 10-$, and 22-a plantations. Of all the base cations and soil layers, exchangeable $\mathrm{K}$ at the depth of $0-10 \mathrm{~cm}$ enhanced most quickly, and it was increased by 1.76 , 3.16, and 4.25 times, respectively, after 5, 10, and 22 years of C. microphylla plantation.

\subsection{Changes of SOC, total N, $\mathrm{pH}$, and EC}

Soil organic carbon (SOC), total N, soil $\mathrm{pH}$, and electrical conductivity $(\mathrm{EC})$ varied significantly $(P<0.05)$ with different plantation years and at different soil depths. Significant inter-subject effects for SOC and total $\mathrm{N}(P<0.01)$ were tested taking plantation year and soil depth as factors (Table 1).

SOC at all the three soil layers was more significantly increased in 10- and 22-a plantations than in 5-a treatment or non-vegetated sand dunes, while it was also greater in 22-a than in 10-a treatment, but no statistical change was observed between 5-a treatment and non-vegetated sand dunes (Fig. 2). Soil total N dynamics was the same as SOC in this study. Soil $\mathrm{pH}$ was higher in 10- and 22-a plantations than in 5-a plantation or non-vegetated sand dunes. Soil EC was significantly greater in 22-a plantation than at other three treatments in the three soil layers, while it was greater in 10- and 5-a plantations than in non-vegetated sand dunes at the corresponding layer (Fig. 2).

\subsection{Relationships between exchangeable base cat- ions and other chemical properties}

Linear regressions of exchangeable $\mathrm{Ca}, \mathrm{Mg}$, and $\mathrm{K}$, and CEC with SOC, total N, soil $\mathrm{pH}$ and $\mathrm{EC}$ in soils under C. microphylla plantations were performed, and the results showed that soil exchangeable properties increased with the increase of SOC, total $\mathrm{N}$, soil $\mathrm{pH}$, and EC (Fig. 3). No Linear regression was tested between exchangeable $\mathrm{Na}$ and $\mathrm{SOC}, \mathrm{N}, \mathrm{pH}$, or EC.

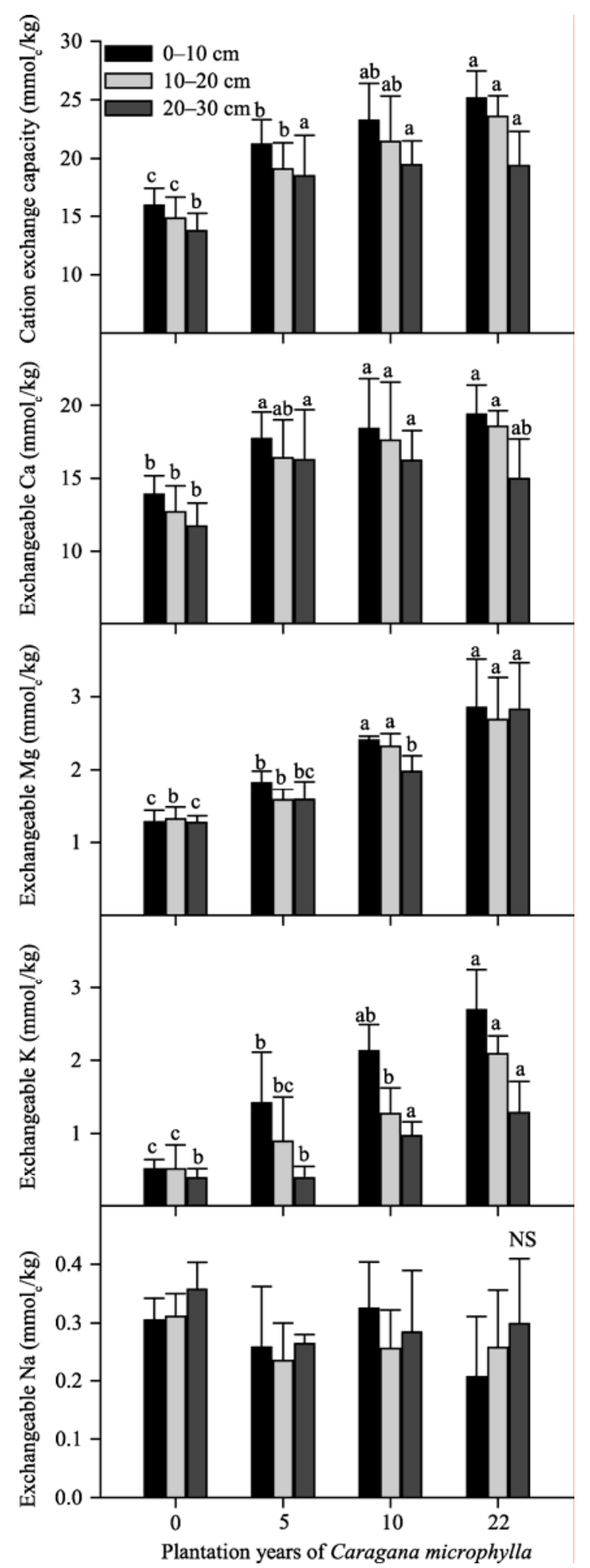

Fig. 1 Exchangeable base cations and cation exchange capacity (CEC) at different soil layers under different plantation years of Caragana microphylla. Values above the column of a single figure followed by different letters in the same soil layer are significantly different at $P<0.05$ according to Duncan's Multiple Range Test. NS means no significant difference at $P<0.05$. 


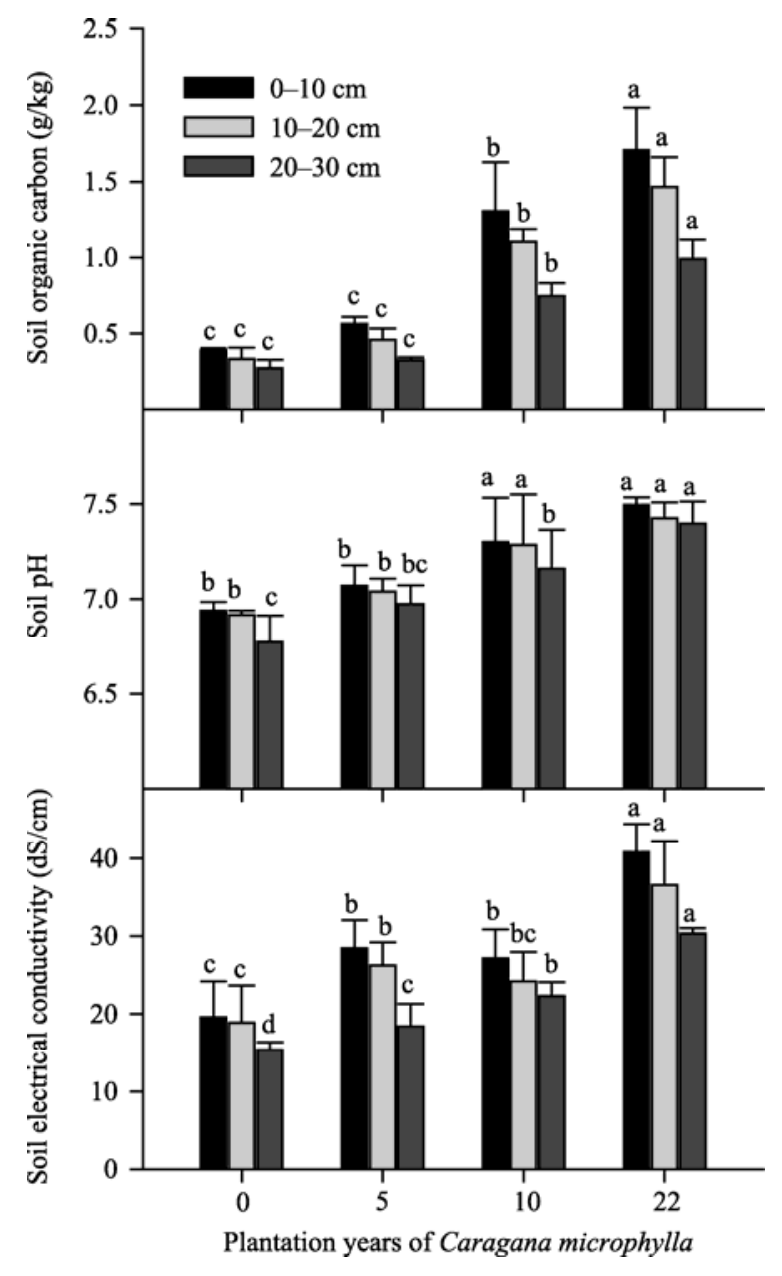

Fig. 2 Soil $\mathrm{pH}$, electrical conductivity $(\mathrm{EC})$, and soil organic carbon (SOC) at different soil layers under different plantation years of Caragana microphylla. Values above the column of a single figure followed by different letters in the same soil layer are significantly different at $P<0.05$ according to Duncan's Multiple Range Test.

\section{Discussion}

\subsection{Variation in soil exchangeable base cations with different plantation years}

The obtained data showed that exchangeable $\mathrm{Ca}, \mathrm{Mg}$, $\mathrm{K}$, and CEC were significantly and positively correlated with the plantation year (Table 2), indicating an accumulation of soil cations along a chronosequence of C. microphylla plantation.

Exchangeable $\mathrm{Ca}, \mathrm{Mg}, \mathrm{K}$, and $\mathrm{Na}$ accounted for $77.07 \%-87.61 \%, \quad 8.00 \%-14.76 \%, \quad 2.24 \%-10.70 \%$, and $0.85 \%-2.60 \%$ of CEC, respectively, with different plantation years and at different soil depths (Table 3), so exchangeable $\mathrm{Ca}$ was the dominant cation in the soil of the semi-arid sandy land. Calcium saturation was decreased, while $\mathrm{Mg}$ and $\mathrm{K}$ saturation were increased with the plantation ages of C. microphylla (Table 3).

Dryland soils generally have very high levels of total $\mathrm{Ca}$, reaching more than $5 \%$ of the soil by weight and occupying $75 \%-85 \%$ of the CEC sites (Troeh and Thompson, 1993). Hydrated cations are relatively small polyvalent ions and tend to preferentially occupy CEC sites, making Ca less bio-available than other cations that are held less strongly. Because minerals that contain $\mathrm{Ca}$ can weather relatively quickly, $\mathrm{Ca}$ is subject to leaching (Marschner and Rengel, 2007). Plant uptake and plant litter can accumulate $\mathrm{Ca}$ in soil surface (Jobbàgy and Jackson, 2001), and increased exchangeable Ca after C. microphylla plantation (Fig. 1), but the comparatively higher leaching rate led to the decrease of Ca saturation in soil with the plantation ages of C. microphylla (Table 3).

A same trend was observed for exchangeable $\mathrm{Mg}$ accumulated in surface soil as exchangeable $\mathrm{Ca}$, but $\mathrm{Mg}$ saturation was slightly increased after C. microphylla was planted. This may also due to the co-effect of plant accumulation and different leaching rates of base cations (Jiang et al., 2005) in this plant-soil system.

Due to $\mathrm{K}$ fixation and sorption to the cation-exchange sites in soils, $\mathrm{K}$ is not easily leached from soils, even over long periods of time. In dryland ecosystems, exchangeable $\mathrm{K}$ accumulates at the surface due to upward transport by plants and accumulation of $\mathrm{K}$ in plant litter (Jobbàgy and Jackson, 2001). Hydrated $\mathrm{K}$ ions are of the same size as ammonium ions and held with about the same strength, whereas they are weakly held relative to $\mathrm{Ca}$ and $\mathrm{Mg}$ ions. Therefore, $\mathrm{K}$ ions are readily exchangeable (Marschner and Rengel, 2007). In this study, no depth effect of exchangeable $\mathrm{K}$ was observed in the 0 -a treatment, while the surface accumulation effect of exchangeable $\mathrm{K}$ was obvious under plantation treatments. Both exchangeable K content (Fig. 1) and K saturation (Table 3 ) were significantly greater at $0-10 \mathrm{~cm}$ than at $20-30 \mathrm{~cm}$ soil layer in the plantation treatments. 


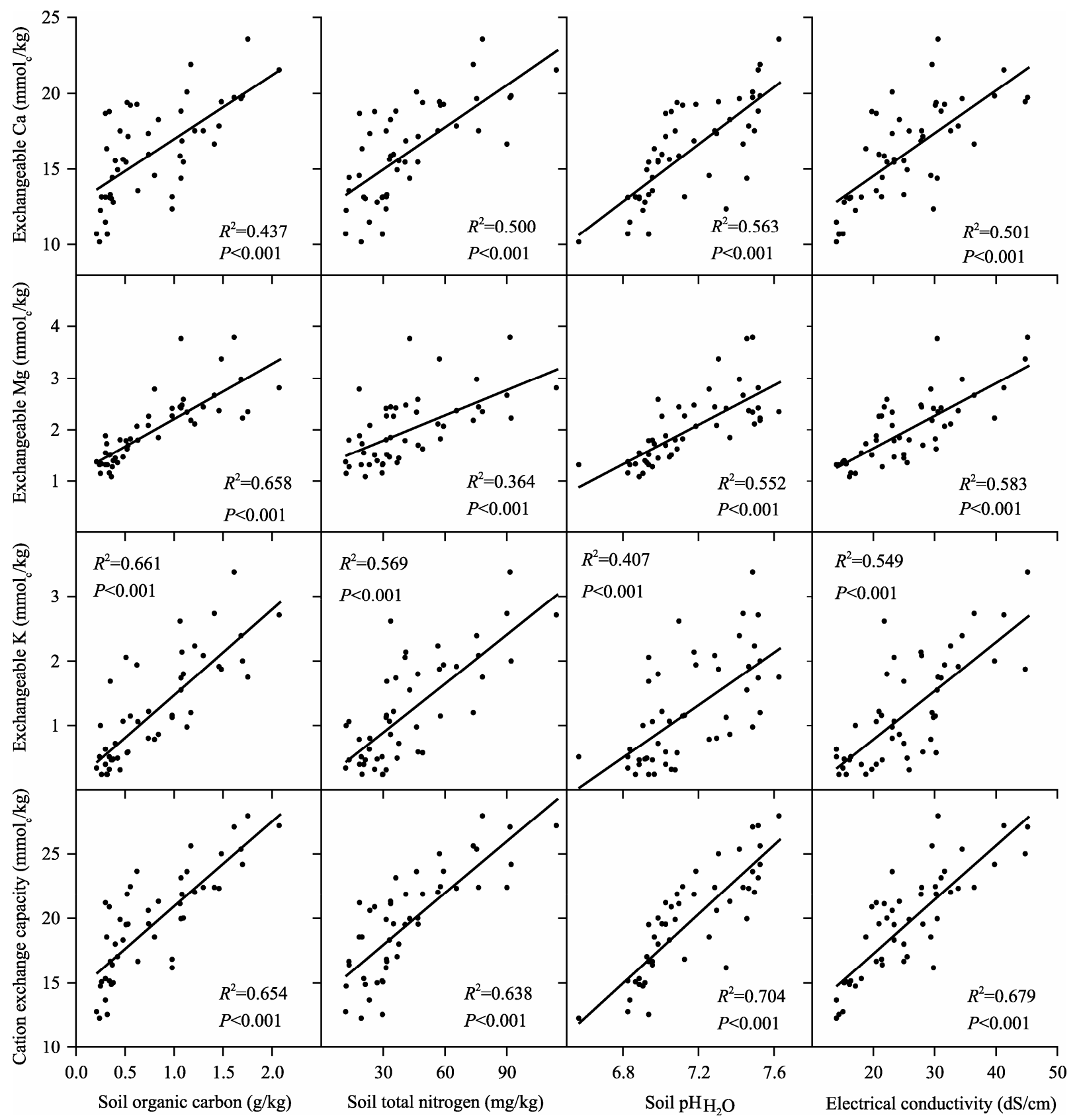

Fig. 3 Linear regression of exchangeable $\mathrm{Ca}, \mathrm{Mg}$, and $\mathrm{K}$, and cation exchange capacity with soil organic carbon (SOC), total nitrogen $(\mathrm{N})$, soil $\mathrm{pH}$ and electrical conductivity $(\mathrm{EC})$ in soils under Caragana microphylla plantations $(n=48)$

Table 2 Correlations between base cations and plantation year $(\mathrm{n}=48)$

\begin{tabular}{ccc}
\hline & Correlation coefficient $\left(R^{2}\right)$ & Significance $(P)$ \\
\hline Exchangeable Ca & 0.379 & 0.008 \\
Exchangeable Mg & 0.869 & $<0.001$ \\
Exchangeable K & 0.762 & $<0.001$ \\
Exchangeable Na & -0.158 & 0.283 \\
Cation exchange capacity & 0.593 & $<0.001$ \\
\hline
\end{tabular}


Table 3 Cation saturation in different C. microphylla plantation years and at different soil depths

\begin{tabular}{cccccc}
\hline Treatment (a) & Soil depth (cm) & Ca saturation (\%) & Mg saturation (\%) & K saturation (\%) & Na saturation (\%) \\
\hline 0 & $0-10$ & $86.89 \pm 1.23$ & $8.00 \pm 0.86$ & $3.18 \pm 0.52$ & $1.92 \pm 0.32$ \\
& $10-20$ & $85.46 \pm 1.84$ & $8.98 \pm 1.40$ & $3.43 \pm 2.23$ & $2.14 \pm 0.49$ \\
& $20-30$ & $85.19 \pm 2.09$ & $9.38 \pm 1.53$ & $2.83 \pm 1.11$ & $2.60 \pm 0.25$ \\
5 & $0-10$ & $83.52 \pm 3.89$ & $8.61 \pm 0.43$ & $6.67 \pm 3.35$ & $1.20 \pm 0.39$ \\
& $10-20$ & $85.50 \pm 4.05$ & $8.32 \pm 0.82$ & $4.96 \pm 3.86$ & $1.22 \pm 0.21$ \\
& $20-30$ & $87.61 \pm 2.52$ & $8.68 \pm 1.07$ & $2.24 \pm 1.54$ & $1.47 \pm 0.29$ \\
10 & $0-10$ & $78.69 \pm 3.95$ & $10.49 \pm 1.45$ & $9.40 \pm 2.52$ & $1.41 \pm 0.39$ \\
& $10-20$ & $81.52 \pm 4.43$ & $11.14 \pm 2.38$ & $6.12 \pm 2.22$ & $1.22 \pm 0.34$ \\
& $20-30$ & $83.25 \pm 2.16$ & $10.22 \pm 1.22$ & $5.07 \pm 1.34$ & $1.46 \pm 0.51$ \\
& $0-10$ & $77.13 \pm 4.29$ & $11.32 \pm 2.08$ & $10.70 \pm 1.99$ & $0.85 \pm 0.50$ \\
& $10-20$ & $78.73 \pm 1.29$ & $11.31 \pm 1.68$ & $8.88 \pm 1.14$ & $1.07 \pm 0.34$ \\
\end{tabular}

Note: data in the table are mean \pm standard deviation for each treatment replicated four times.

Sodium ions are less tightly held to soil particles than $\mathrm{K}, \mathrm{Ca}$ or $\mathrm{Mg}$. Therefore, $\mathrm{Na}$ is more easily leached from soil than the other cations (Marschner and Rengel, 2007); hence no statistical difference was observed among treatments or at soil layers.

\subsection{Effects of soil organic carbon on exchangeable base cations}

Soil particles and organic matter have negative charges on their surfaces, which can be adsorbed by mineral cations, and hence, soil exchangeable cations are highly dependent upon soil texture and organic matter content (Hepper et al., 2006; Gogo and Pearce, 2009). In this study, both exchangeable cations and CEC were significantly and positively correlated with SOC (Fig. 3).

Parfitt et al. (1995) collected 1,043 samples from New Zealand soils, and found that most of the CEC arose from soil organic matter by using multiple regression, and they calculated that CEC was 221-330 $\mathrm{cmol}_{\mathrm{c}} / \mathrm{kg}$ per unit $\mathrm{C}$. The CEC of organic matter was found to vary from 35 to $165 \mathrm{cmol}_{\mathrm{c}} / \mathrm{kg}$ in 18 acid forest soil samples in France, and so represented $10 \%-85 \%$ of the total soil CEC in the tipper soil horizons (Turpault et al., 1996). Measurements made on long-term experiments of cultivated soils in sub-Saharan Africa showed that changes in CEC and SOM were positively correlated, but different SOM played unequal roles as contributing to soil CEC (Guibert et al., 1999). The samples from nine field experiments in Germany showed that the CECs decreased with increased equivalent diameters of soil particles, and varied with $\mathrm{C}$ and $\mathrm{N}$ contents in the size fractions (Leinweber et al., 1993). The results mentioned above supported that SOM is one of the dominant factors influencing CEC in soils. According to this study, CEC was equivalent to $660 \mathrm{cmol}_{\mathcal{C}} / \mathrm{kg} \mathrm{SOC}$. In the sandy soil, both exchangeable base cations and SOC are lower than in other ecosystems, hence SOC may play more contribution to base cations.

\subsection{Effects of soil pH on exchangeable base cations}

According to Fig. 3, CEC increased by about 13.38 $\mathrm{mmol}_{\mathrm{c}} / \mathrm{kg}$ as $\mathrm{pH}$ increased by 1 unit under C. microphylla plantation, of which exchangeable $\mathrm{Ca}, \mathrm{Mg}$, and $\mathrm{K}$ accounted for about 9.47, 1.92, and $2.64 \mathrm{mmol}_{\mathrm{c}} / \mathrm{kg}$, respectively. In this study, a negative contribution of soil $\mathrm{pH}$ to exchangeable $\mathrm{Na}$ was observed, but the relationship between the two variables was not significant.

The sum of positive charges of adsorbed cations that the soil can adsorb at a specific $\mathrm{pH}$ is its CEC (Foth, 1990). As soil pH is increased, the surface negative charge on clay colloids increases and repulsive forces between particles dominate (Renault et al., 2009). Thus, soil CEC is dependent on, and is positively correlated with, soil $\mathrm{pH}$ (Bortoluzzi et al., 2006).

According to Katou (2002), CEC of variable-charge soils is often expressed as a function of $\mathrm{pH}$ and electrolyte concentration. The relationship of CEC $\left(\mathrm{mmol}_{\mathrm{c}} / \mathrm{kg}\right.$ ) with $\mathrm{pH}$ and ion concentration $(\mathrm{EC}, \mathrm{dS} / \mathrm{cm})$ in solution could be expressed with the following equation: 


$$
\begin{aligned}
\mathrm{CEC}= & 7.964 \mathrm{pH}+0.218 \mathrm{EC}-42.897, \\
& \left(R^{2}=0.878, P<0.001\right) .
\end{aligned}
$$

For variable charge soils, modest changes in electrolyte ionic strength are as important in their effect on CEC as are changes in $\mathrm{pH}$ values (Gillman, 1981), and our study also showed the changes of both soluble and exchangeable cations in soil under C. microphylla plantation.

\subsection{Effects of plant-soil interaction on base cations}

Figure 3 showed that the increase of CEC accompanied with the increase of both $\mathrm{pH}$ and SOC. It could be deduced that both $\mathrm{pH}$ and SOC were dominant factors contributing to base cations in soils under $C$. microphylla plantation.

In sandy land ecosystems, C. microphylla plantation can form a fertility island as soils under plants show higher concentrations of $\mathrm{N}$ and organic matter, through N-fixation, carbon-nitrogen interactions, spread of shrubs, and return of plant litters to soil surface (Perroni-Ventura et al., 2010). The fertility island creates a favorable microenvironment for creatures, hosts creatures ranging from bacteria, fungi and nematodes to beetles (Jiang et al., 2007; Cao et al., 2008), and promotes nutrient and water availability for plant growth. The uplift of nutrients from deep soil layers by plants leads to surface accumulation of nutrients under C. microphylla shrubs (Jobbàgy and Jackson, 2004). The accumulation of organic matter and $\mathrm{N}$ modifies soil physical and biological properties, and is beneficial to clay formation. Both organic matter and clay can provide more CEC sites and result in accumulation of exchangeable base cations in topsoil (Havlin et al., 2004). In brief, the variation in exchangeable base cations and CEC is controlled by the interaction of plant and soil, and the interaction of soil physical, chemical, and biological properties, which in turn controls plant nutrient availability in the sandy land ecosystem.

\section{Conclusions}

Soil organic carbon and $\mathrm{pH}$ were the main factors influencing the variation in exchangeable $\mathrm{Ca}, \mathrm{Mg}$ and $\mathrm{K}$, and CEC. As a nitrogen-fixation species, C. microphylla benefits the formation of fertility islands in soils, and hence increases SOC content and nutrient availability. Owing to the increase of $\mathrm{SOC}$ and soil $\mathrm{pH}$, exchangeable $\mathrm{Ca}, \mathrm{Mg}$ and $\mathrm{K}$, and $\mathrm{CEC}$ increased significantly along a chronosequence of C. microphylla plantation. Exchangeable $\mathrm{Ca}$ was the dominant cation in the soil of the semi-arid sandy land. Due to the preferential absorption of cations by plants and different leaching rates of base cations, Ca saturation was decreased, while $\mathrm{Mg}$ and $\mathrm{K}$ saturation were increased with the plantation ages of $C$. microphylla. The results suggest that C. microphylla plantation is beneficial for enhancing soil fertility and is an active way to the ecological restoration of semi-arid sandy lands in North China.

\section{Acknowledgements}

The work was supported by the National Key Basic Research Program of China (2011CB403204) and the Natural Science Foundation of China (31000200). The authors thank the members of the Wulanaodu Desertification Experimental Station under the Chinese Academy of Sciences for technical assistances.

\section{References}

Bortoluzzi E C, Tessier D, Rheinheimer D S, et al. 2006. The cation exchange capacity of a sandy soil in southern Brazil: an estimation of permanent and pH-dependent charges. European Journal of Soil Science, 57(3): 356-364.

Cao C Y, Jiang D M, Teng X H, et al. 2008. Soil chemical and microbiological properties along a chronosequence of Caragana microphylla Lam. plantations in the Horqin Sandy Land of Northeast China. Applied Soil Ecology, 40(1): 78-85.

Cao C Y, Jiang S Y, Ying Z, et al. 2011. Spatial variability of soil nutrients and microbiological properties after the establishment of leguminous shrub Caragana microphylla Lam. plantation on sand dune in the Horqin Sandy Land of Northeast China. Ecological Engineering, 37(10): 1467-1475.

CRGCST (Cooperative Research Group on Chinese Soil Taxonomy). 2001. Chinese Soil Taxonomy. Beijing: Science Press, 72-180.

FAO. 1988. FAO-UNESCO Soil Maps of the World, Revised Legend. World Soil Resources Reports 60. Rome: FAO.

Favre F, Tessier D, Abdelmoula M, et al. 2002. Iron reduction and changes in cation exchange capacity in intermittently waterlogged soil. European Journal of Soil Science, 53(2): 175-183.

Foth H D. 1990. Soil Chemistry. In: Foth H D. Fundamentals of Soil Science ( $8^{\text {th }}$ ed.). New York: John Wiley and Sons, 164-185. Gillman G P. 1981. Effects of $\mathrm{pH}$ and ionic strength on the 
cation-exchange capacity of soils with variable charge. Australian Journal of Soil Research, 19(1): 93-96.

Gogo S, Pearce D M E. 2009. Carbon, cations and CEC: interactions and effects on microbial activity in peat. Geoderma, 153(1-2): 76-86.

Guibert H, Fallavier P, Romero J J. 1999. Carbon content in soil particle size and consequence on cation exchange capacity of alfisols. Communications in Soil Science and Plant Analysis, 30(17-18): 2521-2537.

Havlin J H, Tisdale S L, Nelson W L, et al. 2004. Soil Fertility and Fertilizers: An Introduction to Nutrient Management ( $7^{\text {th }}$ ed.). Singapore: Prentice Hall.

Hepper E N, Buschiazzo D E, Hevia G G, et al. 2006. Clay mineralogy, cation exchange capacity and specific surface area of loess soils with different volcanic ash contents. Geoderma, 135(2): 216-223.

Jiang D M, Li Q, Liu F M, et al. 2007. Vertical distribution of soil nematodes in an age sequence of Caragana microphylla plantations in the Horqin Sandy Land, Northeast China. Ecological Research, 22(1): 49-56.

Jiang Y, Zhang Y G, Liang W J, et al. 2005. Pedogenic and anthropogenic influence on calcium and magnesium behaviors in Stagnic Anthrosols. Pedosphere, 15(3): 341-346.

Jiang Y, Zhang Y G, Zhou D, et al. 2009. Profile distribution of micronutrients in an aquic brown soil as affected by land use. Plant Soil and Environment, 55(11): 468-476.

Jobbàgy E G, Jackson R B. 2001. The distribution of soil nutrients with depth: global patterns and the imprint of plants. Biogeochemistry, 53(1): 51-77.

Jobbàgy E G, Jackson R B. 2004. The uplift of soil nutrients by plants: biogeochemical consequences across scales. Ecology, 85(9): 2380-2389.

Katou H. 2002. A pH-dependence implicit formulation of cation- and anion-exchange capacities of variable-charge soils. Soil Science Society of America Journal, 66(4): 1218-1224.

Kondo J, Hirobe M, Yamada Y, et al. 2012. Effects of Caragana microphylla patch and its canopy size on "islands of fertility" in a Mongolian grassland ecosystem. Landscape and Ecological Engineering, 8(1): 1-8.

Leinweber P, Reuter G, Brozio K. 1993. Cation exchange capacities of organo-mineral particle-size fractions in soils from long-term experiments. Journal of Soil Science, 44(1): 111-119.

Lucas R W, Klaminder J, Futter M N, et al. 2011. A meta-analysis of the effects of nitrogen additions on base cations: implications for plants, soils, and streams. Forest Ecology and Management, 262: 95-104.

Ma C C, Gao Y B, Guo H Y, et al. 2004. Photosynthesis, transpiration, and water use efficiency of Caragana microphylla, C. intermedia, and C. korshinskii. Photosysthetica, 42(1): 65-70.

Marschner P, Rengel Z. 2007. Nutrient Cycling in Terrestrial Ecosystems. Berlin: Springer-Verlag Heidelberg.

Oorts K, Vanlauwe B, Merckx R. 2003. Cation exchange capacities of soil organic matter fractions in a Ferric Lixisol with different organic matter inputs. Agriculture, Ecosystems \& Environment, 100(2-3): 161-171.

Parfitt R L, Giltrap D J, Whitton J S. 1995. Contribution of organic matter and clay-minerals to the cation exchange capacity of soils. Communications in Soil Science and Plant Analysis, 26(9-10): $1343-1355$.

Perroni-Ventura Y, Montan C, Garcia-Oliva F. 2010. Carbon-nitrogen interactions in fertility island soil from a tropical semi-arid ecosystem. Functional Ecology, 24(1): 233-242.

Renault P, Cazevieille P, Verdier J, et al. 2009. Variations in the cation exchange capacity of a ferralsol supplied with vinasse, under changing aeration conditions: comparison between CEC measuring methods. Geoderma, 154(1-2): 101-110.

Su Y Z, Zhao H L. 2003. Soil properties and plant species in an age sequence of Caragana microphylla plantations in the Horqin Sandy Land, North China. Ecological Engineering, 20(3): 223-235.

Su Y Z, Zhang T H, Li Y L, et al. 2005. Changes in soil properties after establishment of Artemisia halodendron and Caragana microphylla on shifting sand dunes in semiarid Horqin Sandy Land, Northern China. Environmental Management, 36(2): 272-281.

Troeh F R, Hompson L M. 1993. Soils and Soil Fertility. New York: Oxford University Press.

Turpault M P, Bonnaud P, Fichter J, et al. 1996. Distribution of cation exchange capacity between organic matter and mineral fractions in acid forest soils (Vosges mountains, France). European Journal of Soil Science, 47(4): 545-556.

van Erp P J, Houba V J G, van Beusichem M L. 2001. Actual cation exchange capacity of agricultural soils and its relationship with $\mathrm{pH}$ and content of organic carbon and clay. Communications in Soil Science and Plant Analysis, 32(1-2): 19-31.

Wang S K, Zhao X Y, Qu H, et al. 2010. Variation in soil water content to rainfall under Caragana microphylla shrub in Horqin Sandy Land. Journal of Arid Land, 2(3): 174-179.

Yue G Y, Zhao H L, Zhang T H, et al. 2008. Evaluation of water use of Caragana microphylla with the stem heat-balance method in Horqin Sandy Land, Inner Mongolia, China. Agricultural and Forest Meteorology, 148(11): 1668-1678.

Zhao Y Z. 2005. The distribution pattern and ecological adaptation of Caragana microphylla, C. davazamcii and C. korshinskii. Acta Ecologica Sinica, 25(12): 3411-3414. 